\title{
Research on the Genetic Map of Red Culture in Zaozhuang
}

\author{
Zhang Zhiguo \\ School of Communication, Zaozhuang University
}

\begin{abstract}
The history of Zaozhuang's modern industrial development for more than 100 years and its position in the National Anti-Japanese War and Revolution have determined the multidimensional and comprehensive nature of Zaozhuang's red culture. Therefore, the genetic map of Zaozhuang's red culture must be based on the overall situation and be drawn from multiple dimensions. These dimensions mainly include the red collective, the red hero, the red story, the red spirit and the red story.
\end{abstract}

Keywords—Red culture; Red gene; Map; Red hero; Red story

\section{INTRODUCTION}

Throughout the history of struggle and national culture of the Chinese Nation, the Chinese Nation has been inherited from birth to the present, in the final analysis, because it is maintained by its inherent cultural genes. The excellent genes of Chinese culture have various manifestations and spiritual connotations. The great practice of revolution, construction and reform by the Chinese people led by the Communist Party of China has concisely generated the red gene, which is not only the dependence of the national emotion of the Chinese nation, but also the spiritual destination of the Chinese nation's constant self-improvement and the forward action force of the Chinese nation. Since the Eighteen Party Congress, General Secretary Xi Jinping has repeatedly requested that the red gene must be passed down from generation to generation. Since entering the new era, many places have made effective exploration in inheriting the red gene and helping local economy.

From the provincial level of Fujian, the project of protecting, inheriting and promoting red culture in Fujian is based on the gene of red

culture in Fujian, making good use of red resources, spreading the spirit of red, and producing positive social effects From the perspective of prefecture level cities, the practice of Linyi in Shandong is also worth learning from. Since the reform and opening up, Linyi's economic development has been remarkable. It has formed two business cards as the famous old revolutionary area in China. One is Yimeng Spirit (soft business card); the other is Linyi Mall (hard business card). These two business cards resonate with each other, promote each other and complement each other, forming a new highlight of Linyi's old revolutionary area.
On March 8, 2018, when attending the deliberations of the Shandong delegation at the first session of the 13th National People's Congress, General Secretary Xi Jinping gave important instructions on inheriting red genes and promoting the revitalization of rural culture, and made clear requests[1]. Zaozhuang, like Linyi, is also a revolutionary old area and a red hot land. It has rich red genetic resources. Zaozhuang's first Party branch was established as early as 1926 in the mining area of Zaozhuang Coal Mine Group. Since then, the Red Gene and Red Belief of the Party have deeply rooted in a large area of coal fields. The Taierzhuang War in Zaozhuang, the Railway Guerrillas established in Zaozhuang area, the 115thDivision of South Shandong Anti-Japanese Base Area and the Canal Branch centered on Baodu Mountain are the red genetic resources of Shandong and even the national civilization. Therefore, the red gene has a great role in the innovation and sustainable development of Zaozhuang-a resource-based cities. It is not only feasible but also of great significance to study the application path of the red gene in the resource-based city of Zaozhuang.

\section{THE DISCOVERY OF RED GENES IN ZAOZHUANG}

The most characteristic representative of modern Chinese culture genes is the Chinese red culture gene. The Red Culture Gene of China includes not only a series of soothing revolutionary and construction stories emerged in the process of the Chinese people's democratic revolution and socialist revolution and socialist construction under the leadership of the Communist Party of China, but also the revolutionary spirit displayed by the Communists in the course of the Chinese revolution, such as the spirit of the Red Ship. Jinggang Mountain Spirit, Yan'an Spirit, Xibaipo Spirit and the Spirit of Flood Relief in the New Period, Earthquake Relief Spirit, Beijing Olympic Spirit, Manned Space Spirit, etc. These red genes are not only the spiritual core of the Communist Party of China, but also the spiritual bond of the Chinese Nation. She inspired Chinese from generation to generation to advance bravely for the great rejuvenation of the Chinese Nation. All these excellent cultural genes show that Chinese culture still has vigorous vitality, and continues to inherit in various fields, which provides power support and spiritual guidance for China's economic development and the realization of the great Chinese dream. 
In the history of the development of Chinese civilization, Shandong has bred Qilu civilization, an important civilization of Chinese civilization, from which Qilu culture, an important source of Chinese culture, has emerged. From Wang Jingmei, who came out of Shandong Province in the First Congress of the Communist Party of China, to countless laborious people who participated in and supported the revolution in succession, to Jiao Yulu, Kong Fansen, and Zhu Yanfu, Li Denghai, the model of the times, all emerged here. So the red gene has created the bright spiritual background of modern civilization in Shandong. It is this background color that guides the cadres and masses of Shandong to work hard and unremittingly, to win successes in Shandong's new democratic revolution and socialist construction, and to continue to guide the historic great changes in Shandong.

The red culture gene of Shandong is not only the precious spiritual wealth of Shandong people, but also a powerful spiritual force to overcome difficulties and forge ahead at a new historical starting point[2]. At present, our province is in the exploratory period of a new development model, and the key period of strategic transformation from big to strong requires more conscious and solid responsibility, which is the spiritual support and guidance. Linyi has fully exploited the local red culture gene, built up the party spirit education base and developed the red tourism project. They have touched thousands of Party members and ordinary people with the fresh Yimeng revolutionary story and the Yimeng spirit of blending military and civilian life, death and co-creation, and encouraged Yimeng people to start their own businesses and achieve great success with Yimeng spirit.

Zaozhuang, which also has rich red cultural resources, has a good tradition in the exploration and application of red culture, but it has not played its due role. Take the film as an example. In the 1950s, Zaozhuang became popular all over the country because of the red film Railway Guerrilla. When "Railway Guerrilla" was broadcasted, let alone the grand spectacle of watching movies, the ratings of the movie re-broadcast on CCTV Film Channel can be seen. According to statistics of relevant departments, from 1997 to 2011, the film "Railway Guerrilla" was broadcasted 31 times on CCTV6. The ratings were very high every time, reaching a maximum of $2.94 \%$. By June 2011 , the ratings were still as high as $1.88 \%$, which was no less impressive than the latest blockbusters. The TV series "Railway Guerrillas" became popular among major satellite TV stations in 2005 and won the first place of BeijingTV's Excellent Viewing Award in the whole year; the second place of Chongqing TV's Reality Viewing in the whole year in 2005; the special award of Shanghai Jiao Guang News and Media Group for film review in 2005; the 7th of top ten of the National City TV Series in 2005; and the best TV Jilin TV Drama Best Award in 2005. Its ratings in other provinces or municipalities directly under the Central Government in 2005 are also very high, such as in Guangdong, Guangxi, Fujian, Jiangsu, Shandong, Shanxi, Hebei, Chengdu and so on. The popularity of Railway Guerrilla Team 2 in Guangdong, Liaoning, Henan and Anhui in 2011 proves once again the artistic charm of red classic movies and TV dramas. It also shows that red culture is accepted by the general public in both revolutionary and peaceful times, and has a far-reaching impact on them. Therefore, in the new era, the red culture rooted in Zaozhuang is not only promising to do a good job in cultural industry, but also in Shandong Province to comprehensively deepen the reform and implement the transformation of old and new kinetic energy, cultural and creative industries as the top ten industries of today's development of the red cultural industry is at the right time.

Although Zaozhuang was built late, Zaozhuang's red culture was not too late. As early as 1923, the Central Committee of the Communist Party of China sent a comrade whose family name is $\mathrm{Li}$ to the Zaozhuang mining area to launch the workers' movement. In 1926, under the leadership of Ji Zirui, 19 Party members, including Zhang Fulin, Jiang Fuyi, Guo Changqing, Wang Wenbin, Du Baocai and Wu Junshan, were developed and the Zaozhuang Mining Area Branch of the CPC was established, which is the first Party Branch in Zaozhuang Mining Area and the first Party Branch in Zaozhuang Area. The red culture of Zaozhuang begins to breed and has rich connotation. It includes not only the hard history of the tortuous establishment of the Party organizations led by the early Communist Party of China, including the workers' movement in the mining areas led by the Party, the revolutionary activities of the people in Zaozhuang and the righteous actions to support the revolution, but also the various battles that took place in Zaozhuang, such as the Taierzhuang Battle and the South Shandong Battle, as well as the Railroad Guerrilla Campaign. The moving stories of the fighting groups and heroes of the fighting groups such as the Railroad Guerrilla, the Yixian Detachment, the Canal Detachment, the Independent Detachment, the Wenfeng Brigade and the Sulu Detachment.

At present, although Zaozhuang has excavated a series of movies and TV plays such as "Railway Guerrilla" and "Bloody Battle Taierzhuang", developed some tourist attractions based on red culture, such as Railway Guerrilla Film and TV City and Taierzhuang Ancient City, and established a base for Party spirit education of Railway Guerrilla, it has a history of more than 90 years of red culture development of our Party in Zaozhuang. Zaozhuang is the birthplace of China's early national industry; it has a history of more than 100 years; it has been invaded by the Japanese and experienced the deepest national pain; it has witnessed the most bitter war of resistance against Japan by the Chinese Kuomintang; and it has also bred the early red culture of Shandong. All these are the soil nurtured by Zaozhuang red culture, the background of Zaozhuang red culture, or the catalyst of Zaozhuang red culture [3]. Therefore, Zaozhuang's red culture should be multidimensional and comprehensive. It should not be covered by the red brands such as the Railway Guerrilla Forces. Therefore, the exploration of Zaozhuang's red culture gene should also be multi-dimensional and comprehensive. 


\section{Genetic MAP OF Red CUlture IN ZAOZHUANG}

The history of Zaozhuang's modern industrial development over 100 years and Zaozhuang's position in the National AntiJapanese War and Revolution determine the multidimensional and comprehensive nature of Zaozhuang's red culture. The multidimensional and comprehensive nature of Zaozhuang red culture determines that the gene of Zaozhuang red culture is multidimensional and comprehensive, so drawing the genetic map of Zaozhuang red culture must be based on the overall situation and start from multiple dimensions.

First dimension: Red collectives. In the hot soil of Zaozhuang, not only the anti-Japanese base area of Baoqiao was established, but also countless battle groups of our Party emerged. Among these battle groups, the First Party branch established by our Party is the Zaozhuang Mining Area Branch of the Communist Party of China, the Railway Guerrilla Team, the Yixian Branch, the Canal Branch, the Independent Branch, the Wenfeng Brigade and the Sulu Branch. This Red Army and the Eighth Division of the PLA have gone through more than a thousand battles and composed the song of colorful movement of the revolution with their blood. They mainly attacked and liberated more than 30 cities above the county level, wiped out more than 220,000 enemies and seized a large number of weapons and equipment; among them, more than 160 excellent combat groups emerged, such as Guo Jisheng Company, Li Xun Wen Xuan Platoon, Pingshan Company, Hongyi Company, Luoyang Camp, Chen Jinhe Squad and Xuchang Company, etc. These fighting collective are known as "the little cub in Chen Yi's sleeve", or known as "excellent first-class corps". These collective fighting stories are the main background of Zaozhuang's red culture gene, as well as the important wealth and inexhaustible spiritual power of Zaozhuang's sustainable economic development in the new era.

Second dimension : Red hero. In the Red Revolution led by the Communist Party of China in Zaozhuang, not only a number of red fighting collectives emerged, but also a large number of anti-Japanese heroes emerged. Only the Eighth Division of the PLA emerged more than 1800 heroic models and more than 40,000 meritorious officials. These antiJapanese heroes have not only the leadership of the red collective but also the ordinary fighters. It is their bloody struggle that brought the victory of the Chinese revolution. The heroic leaders of these red collectives include Hong Zhenhai, Liu Jinshan, Du Jiwei, Wang Zhisheng, Guo Zihua, Zhang Guangzhong, He Yiping, Tong Lusheng, Zhu Yaqing, Zhang Xinhua, Meng Xianzhen, Ji Zirui, Zhang Fulin, and other ordinary fighters such as Class A fighting heroes Xu Guangtian, Yang Jiashun and Yang Qingping. These red Heroes'growing experience, fighting stories and fearless revolutionary struggle spirit are all treasures that Zaozhuang red gene can continue to dig deeply. At present, the novel "Railway Guerrilla" and the movie and TV series "Railway Guerrilla" based on Hong Zhenhai are very successful. The literary works, which are based on other characters, have not yet appeared, or have appeared but have little influence. Therefore, Zaozhuang, which has rich red culture genes, has great potential in the exploration of red culture, especially in the propaganda of red heroes and the spiritual leading role of red characters in the sustainable development of Zaozhuang.
Third dimension: Red story. The red revolutionary hot spot and the revolutionary hero city of Zaozhuang has left numerous red stories. These stories include not only the collective fighting stories of the red collectives, but also the personal struggles and fighting stories of the red heroes, such as Guo Zihua's medical practice in the mining area, Zhu Daonan's Zouwu Riot, Sun Bolong's skillful fight in Duzhuang, Cao Buqiao, Tanghu, Li Guoyi, Yangzhuang, Hou Ji and other battles, and the red legends of the "Flying motors to rob machine guns"of the Railway Guerrilla, "Bloodstaining Foreign Operations" and "Rob Ticket Trains Wisely" is still widely read in the south of Shandong Province. These stories are an important one-dimensional in the genetic map of red culture in Zaozhuang. These stories are not only the classic cases of red gene inheritance, but also the spiritual food for generations of young people. They also play an important role in the sustainable development of Zaozhuang.

Fourth Dimension: Red spirit. In the growth and battle of Zaozhuang red collective and red heroes, what makes the leaders or red heroes of the red collective be able to face the difficult situation and overcome the difficulties with firm will, courage and courage, and win the final victory over the enemy is the red spirit displayed on them. This red spirit is rooted in the firm belief in the Chinese Communist Party and rooted in the yearning for a better life. So by digging out the red gene, we can discover the red spirit behind many red genes, and provide spiritual power and intellectual support for the sustainable development of Zaozhuang through spiritual inheritance.

Fifth Dimension : the story of Support Red. The reason why the red battle groups and red heroes are constantly emerging in Zaozhuang, a red hot soil, is that ordinary people who support the Red Revolution are indispensable. Therefore, excavating the story of how ordinary people support or respond to the Red Revolution during the revolutionary war is also an integral part of Zaozhuang red culture gene. The story of Red Sister-in-law's support for the revolution in Yimeng Mountains of Linyi also tells the story of thousands of people pushing a wheelbarrow to support the PLA going south. Zaozhuang, as a hot spot of Shandong Red Revolution, must also have a large number of folk stories supporting the revolution besides Fanglin's sister-in-law. However, the collection of these stories is not in place. If we do not collect them in time, I am afraid that with the passage of time, a large number of witnesses supporting the revolution will die, and these stories will disappear. The clouds of history are in the air. Therefore, in order to explore the red culture gene in all aspects, we should strengthen the excavation of the red story in time.

The red culture gene of Zaozhuang not only has the common characteristics of Chinese red culture, but also has the characteristics that it does not have with the red culture of other regions. The red culture of Zaozhuang originated from the representative enterprises of national industry in the early period of China (ZTE), and then grew steadily in the course of resisting the aggression of Japanese imperialism. Therefore, the ecological environment of Zaozhuang's revolutionary history determined that the objects of the struggle of Zaozhuang's red culture were not only Chinese national capital, feudal vagueness, Kuomintang factions, Japanese puppet forces and 
other objects of struggle, the soil of their cultural birth and its complexity, can be said to be concentrated in the main complex elements of the old China. However, due to the special geographical location, topography, landform and special historical and cultural environment of Zaozhuang, the red culture of Zaozhuang has its own distinct characteristics. Zaozhuang is a mountain area as well as a lake area, with backward feudal system and advanced national industry at that time, which created the particularity of red culture in Zaozhuang.

\section{CONCLUSION}

The red culture of Zaozhuang includes not only the red struggle culture of Shandong Province, but also the struggle culture of the lake area of Weishan Lake, the struggle culture of the peasants in the countryside and the struggle culture of the workers in the mining area. This has created the typicality and diversity of red culture in Zaozhuang, and left abundant red cultural resources for Zaozhuang. These red cultural resources are the priceless wealth of Zaozhuang. How to accurately connect these wealth with the current economic development of Zaozhuang is a major problem faced with the people of Zaozhuang. Next, according to the previous research, we will discuss the application path of Zaozhuang red gene in the sustainable development of Zaozhuang, in order to give some inspiration to the sustainable development of Zaozhuang.

\section{REFERENCES}

[1] Lian Weidong, Inherit Red Gene and Carry Forward Traditional Culture [EB/OL]. http://news.shm.com.cn/2018-03/11/content_4704361.htm, 2018-3-11.

[2] Ge Zhu Chun. Wang Junmin comes to our city to investigate [N]. Dongying Daily, 2018-07-03.

[3] Qiu Shoujie. Historical value of red culture[N].Strait Communication, 2016-11-01. 